\title{
The use of combination forecasting approach and its application to regional market analysis*
}

\author{
Arvydas Jadevicius ${ }^{1}$ \\ ${ }^{1}$ Royal Agricultural University, Cirencester, Gloucestershire, United Kingdom \\ (email: arvydas.jadevicius@rau.ac.uk)
}

Received: 30 July 2014/Accepted: 14 October 2014

\begin{abstract}
Econometric modelling of the property market has been exercised for several decades. Despite advancements in the field, there is still an element of uncertainty in property market modelling and forecasting. This uncertainty arises due to prevailing modelling practices. On one hand, researchers select the best performing model and disregard alternatives. On the other hand, researchers face a dilemma in deciding which model to choose when competing specifications produce different results. A possible solution is to use the principle of combination forecasting to reduce uncertainty and improve accuracy. Certainly, combination forecasting has its limitations. One criticism is that combination forecasting has predominantly focused on national property markets analysis. To enhance the application of combination forecasting, it would be useful to use it in research on regional markets analysis.
\end{abstract}

Key words: Combination, Forecasting, Property, Regional, Uncertainty

\section{Introduction}

Econometric modelling of property markets now spans several decades (Rosen 1984, Hekman 1985, Wheaton 1987, Barras 1994, 2009, Brooks, Tsolacos 2010). The literature on the subject suggests, however, that further improvements can be made. Studies on direct (inter alia, Tsolacos 1995, D’Arcy et al. 1999, Brooks, Tsolacos 2000, Wilson et al. 2000, Fss et al. 2012) and indirect (inter alia, Newell et al. 2002, Gallimore, McAllister 2004, Newell, MacFarlane 2006, McAllister, Kennedy 2007, IPF 2012) comparisons of the accuracy of property forecasting models suggest that its accuracy varies. Such variations occur due to the model's specification, poor data, and potential oversights in economic forecasts (e.g. inaccurate forecasts of the determinants of output). Forecasting inaccuracy can also arise because of the specific accuracy measure selected or measurement errors; the trade-off between investments into model development and availability of the resources; inadequate weight allocation to selected variables; unstable or changing patterns or relationships, and random shocks (Makridakis 1989, Fildes 1991, Newell et al. 2002, McAllister et al. 2005).

Furthermore, property market researchers use discretion in selecting the best model for forecasting, which is based on the model's accuracy or its statistical complexity/sophistication (D'Arcy et al. 1999, Stevenson, McGarth 2003, Karakozova 2004). This

\footnotetext{
* The author would like to thank Dr. Simon Huston as well as anonymous reviewers for valuable comments and suggestions regarding this manuscript.
} 
practice, however, has been criticised by researchers, including Granger (1969), Wood (1976) and Wallis (2011). The criticism is that forecasters, once they have selected the best performing model, neglect alternatives. When the objective is to obtain the best possible forecast, this is unproductive, as rejected methods may contain useful independent information.

Apart from accuracy, the selection of alternative model specifications can generate different results. For example, Makridakis et al. (1998) examine what a decision maker should do if a time series model predicts a 10 per cent decline in sales while a regression model shows that sales will increase by 2.5 per cent over a given time horizon. Figure 1 displays Makridakis et al.'s forecasts obtained from single exponential smoothing (SES), Holt's linear trend (HLT) and damped smoothing (DS) models, which show different ex-ante and ex-post modelling estimates. This example demonstrates the predicament researchers and decision makers face when confronted with models that generate different results whilst each contains useful information about the object being modelled.

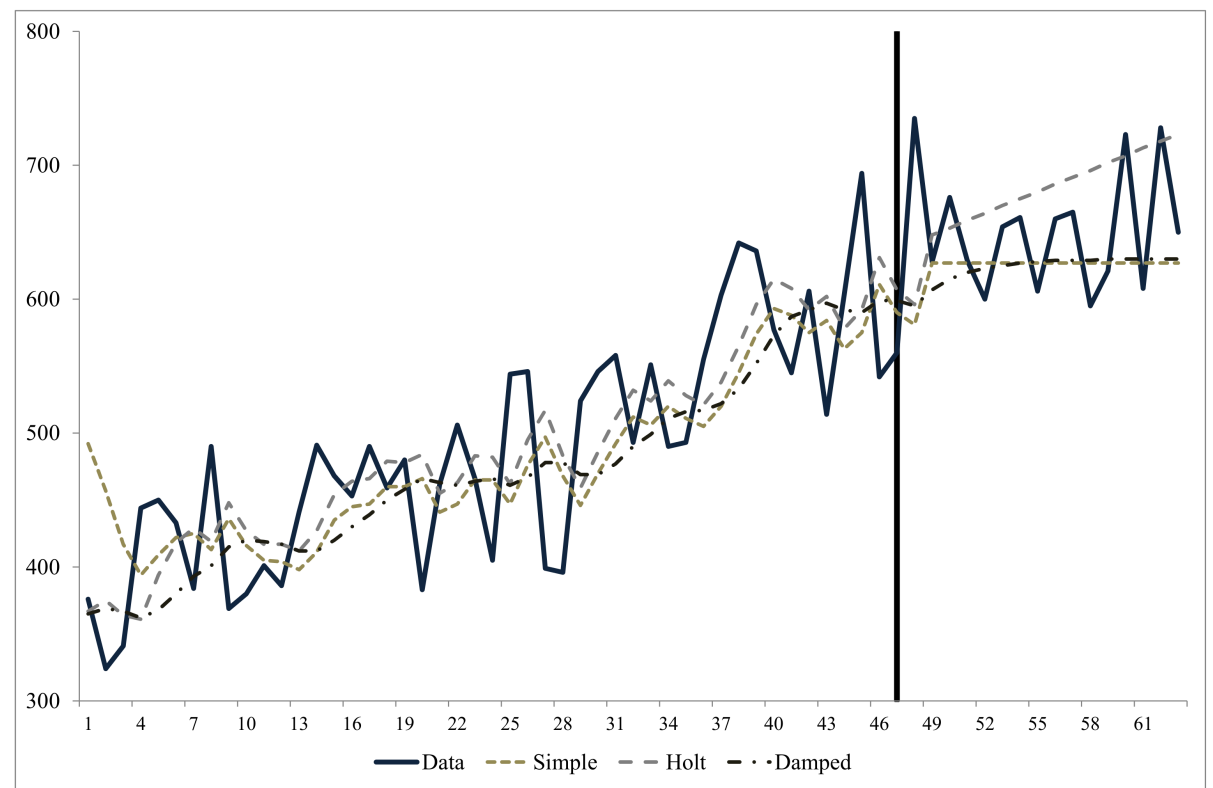

Figure 1: Model fit and forecasts for SES, HLT and DS models (Adapted from Makridakis et al. 1998)

\section{Pursuit for Complexity}

One solution for choosing a best model is to use upgraded modelling techniques, which also involves training researchers to work with more complex methods (Makridakis et al. 1998). Makridakis et al. (1998) acknowledge that inputs pressure on resources, i.e. financial and human capital. Additionally, empirical research in environmental studies, economics and physiology does not support the assumption that complexity improves modelling accuracy (inter alia, Dorn 1950, Armstrong 1986, Clements, Hendry 2003, Orrell, McSharry 2009).

Outside of real estate, the findings of Dorn (1950), Hajnal (1955), Armstrong et al. (1984), Armstrong (1986) and Clements, Hendry (2003) did not favour complex forecasting models. Complex models, which typically incorporate large amounts of inputs, become overly complicated and thus exhibit poorer accuracy. Simple forecasting techniques, ceteris paribus, outweigh the more complex econometric structures. Recent evidence from Buede (2009) and Orrell, McSharry (2009) also favour less complex models, while Armstrong et al. (2015) advocate for forecasting conservatism.

In property forecasting literature, simple models such as exponential smoothing, simple regression and ARIMA specifications outperform the more complex forecasting tech- 
niques, such as VAR and econometric models (Chaplin 1999, Newell et al. 2002, Stevenson, McGarth 2003, Jin, Grissom 2008).

\section{Combination Forecasting}

\subsection{Principles of Combination Forecasting}

Combination forecasting is an alternative potential solution for improving forecasting accuracy. Individual models use different data, are specified on different parameters and their applications vary depending on the forecasting horizon. Therefore, these models only partially reflect reality, regardless of their complexity (Makridakis et al. 1998, Goodwin 2009). Extensive theoretical and empirical findings about combination forecasting suggest that it can achieve greater modelling accuracy (Bates, Granger 1969, Mahmoud 1984, Clemen 1989, Makridakis 1981, 1989, Fildes 1991, Stock, Watson 2004, Kapetanios et al. 2008, Goodwin 2009, Pesaran, Pick 2011, Wallis 2011).

Despite its improved accuracy, several critiques of combination forecasting exist. Bates, Granger (1969), and more recently Kapetanios et al. (2008) and Banternghansa, McCracken (2010), observe that combination forecasting does not necessarily lead to better forecasting performance. Bates, Granger (1969) comment on the issue of positively balanced forecasts. Kapetanios et al. (2008) note a difficulty in the data generating process of combination forecasting. Kapetanios states if the correctly specified model is identified but the data generating process remains unchanged, the overall accuracy will remain poor. Banternghansa, McCracken (2010) advocate caution in using this approach.

\subsection{Combination Forecasting Within Real Estate}

To date, combination forecasting has not been extensively applied in real estate research (Bradley et al. 2003). Extant real estate studies focus on residential property markets (inter alia, Bradley et al. 2003, Pagourtzi et al. 2005, Fleming, Kuo 2007, Drought, McDonald 2011, Gupta et al. 2011). Fildes (1991) combines sector specific forecasts obtained from a panel of construction industry experts, while more recently, Cabrera et al. (2011) use combination forecasting to predict international securitized real estate returns. Gupta et al. (2011) assess forecasting accuracy of alternative time series models in predicting the dynamics of the United States real house price index.

\section{How Can Combination Forecasting Advance Regional Real Estate Re- search?}

The previous overview of property market analysis research illustrates how the field has advanced over time. In response to model disparities, researchers have turned to complex or combination forecasting solutions. Neither solution has resolved the matter of regional disparities in market analysis (Isserman 1993, Bailly, Coffey 1994, Koschinsky et al. 2014). This echoes the commentary by Jones (1995) on difficulties related to the analysis and prediction of local property markets, which persists nearly 20 years after Jones' critique.

Considering that national economies are constituted by a combination of simple parts and simple repeated transactions (Dalio 2014), national property markets are agglomerations of local markets whose subsystem dynamics drive the overall performance of the property market. Thus, greater national property market forecasting accuracy should involve an appreciation of specific regional markets and the integration of their dynamics into an overall national model. A greater appreciation of the changes in local property markets would ultimately generate greater accuracy in national estimates.

Local and regional market forecasts are not frequently employed, although literature is replete with regional investigations. Earlier studies by Grubel (1968), Friedman (1971), and Smith, Shulman (1976), as well as more recent studies by Malizia, Simons (1991), Eichholtz et al. (1995), Lee (1998b,a), Lee, Stevenson (2005), Adair et al. (2006), and Kohlert (2010) demonstrate the benefits of regional and sector specific investment portfolio diversification. These findings provide property market participants with "insights into the sector/regional decision choice" (Lee, Stevenson 2005, p. 408). 
This shows that there is room to strengthen forecasting by integrating regional and local market dynamics. To date, combination forecasting has focused on the national rather than on regional property markets. To the best of the author's knowledge, only Rapach, Strauss (2007) have used combination forecasting for regional market analysis, which they employed for real housing price growth forecasting in eight American states.

Property market researchers are therefore encouraged to perform greater regional markets analysis and employ combination forecasting to aid their work, which would enhance their regional modelling results. Updated local/regional property market estimates could subsequently complement national market analysis.

\section{Conclusion and research implications}

This discussion has demonstrated the breadth of modelling techniques available to property market researchers. Over the years, modelling techniques have advanced; however, as noted above, a degree of inaccuracy persists. Inaccuracy in property market forecasting mostly arises due to prevailing modelling practices. One way to mitigate inaccuracy is to make models more complex, but this is no panacea.

Combination forecasting is a better solution, but still has some limitations. One issue is that, to date, most combination forecasts are restricted to the analysis of individual assets or focus on national property markets. With the benefit of regional diversification widely acknowledged, analysts and researchers are therefore encouraged to focus on lo$\mathrm{cal} /$ regional market dynamics and integrate combination forecasting into models to aid their forecasts.

\section{References}

Adair A, McGreal S, Webb J (2006) Diversification Effects of Private versus Public Real Estate in the UK. Paper presented at the Pacific Rim Real Estate Society (PRRES) Conference, Auckland

Armstrong J (1986) Research on forecasting: A quarter-century review. Interfaces 16: 89-109

Armstrong J, Ayres R, Christ C, Ord J (1984) Forecasting by extrapolation: Conclusions from 25 years of research [with comment and reply]. Interfaces 14: 52-66

Armstrong J, Green K, Graefe A (2015) Golden rule of forecasting: Be conservative. Journal of Business Research

Bailly A, Coffey W (1994) Regional science in crisis: A plea for a more open and relevant approach. Papers in Regional Science 73: 3-14

Banternghansa C, McCracken MW (2010) Real-time forecast averaging with ALFRED. Working Paper 2010-033A

Barras R (1994) Property and the economic cycle: Building cycles revisited. Journal of Property Research 11: 183-197

Barras R (2009) Building Cycles: Growth and Instability (Real Estate Issues). WileyBlackwell, London

Bates J, Granger C (1969) The combination of forecasts. Operational Research Society 20: $451-468$

Bradley M, Gordon J, Mcmanus D (2003) Method for combining house price forecasts. United States Patent 6609109

Brooks C, Tsolacos S (2000) Forecasting models of retail rents. Environment and Planning $A$ 32: 1825-1839

Brooks C, Tsolacos S (2010) Real Estate Modelling and Forecasting. Cambridge University Press, Cambridge 
Buede D (2009) Errors associated with simple versus realistic models. Computational \& Mathematical Organization Theory 15: 11-18

Cabrera J, Wang T, Yang J (2011) Linear and nonlinear predictability of international securitized real estate returns: A reality check. Journal of Real Estate Research 33: $565-594$

Chaplin R (1999) The predictability of real office rents. Journal of Property Research 16: $21-49$

Clemen R (1989) Combining forecasts: A Review and Annotated Bibliography. International Journal of Forecasting 5: 559-583

Clements M, Hendry D (2003) Economic forecasting: Some lessons from recent research. Economic Modelling 20: 301-329

Dalio R (2014) Economic principles. Bridgewater associates, LP

D'Arcy E, McGough T, Tsolacos S (1999) An econometric analysis and forecasts of the office rental cycle in the dublin area. Journal of Property Research 16: 309-321

Dorn H (1950) Pitfalls in population forecasts and projections. Journal of the American Statistical Association 45: 311-334

Drought S, McDonald C (2011) Forecasting house price inflation: A model combination approach. Discussion Paper Series 32., Reserve Bank of New Zealand

Eichholtz P, Hoesli M, MacGregor B, Nanthakumaran N (1995) Real estate portfolio diversification by property type and region. Journal of Property Finance 6: 39-59

Fildes R (1991) Efficient use of information in the formation of subjective industry forecasts. Journal of Forecasting 10: 597-617

Fleming M, Kuo CL (2007) Method and apparatus for predicting and reporting a rea estate value based on a weighted average of predicted values. United States Patent 7305328

Friedman H (1971) Real estate investment and portfolio theory. The Journal of Financial and Quantitative Analysis 6: 861-874

Fss R, Stein M, Zietz J (2012) A regime-switching approach to modelling rental prices of U.K real estate sectors. Real Estate Economics 40: 317-350

Gallimore P, McAllister P (2004) Expert judgement in the processes of commercial property market forecasting. Paper presented at the European Real Estate Society (ERES) Annual Conference, Milan

Goodwin P (2009) New evidence on the value of combining forecasts. Foresight: The International Journal of Applied Forecasting 12: 33-35

Granger C (1969) Investigating causal relations by econometric models and cross-spectral methods. Econometrica 37: 424-438

Grubel H (1968) Internationally diversified portfolios: Welfare gains and capital flows. The American Economic Review 58: 1299-1314

Gupta R, Kabundi A, Miller S (2011) Forecasting the US real house price index: Structural and non-structural models with and without fundamentals. Economic Modelling 28: 2013-2021

Hajnal J (1955) The prospects for population forecasts. Journal of the American Statistical Association 50: 309-322

Hekman J (1985) Rental price adjustment and investment in the office market. Real Estate Economics 13: 32-47 
IPF - Investment Property Forum (2012) Reassessing the accuracy of UK commercial property forecasts. Accessed 12 february, 2013, available online at: https://www.ipf.org.uk/membersarea/downloads/listings1.asp?pid=36

Isserman A (1993) Lost in space? on the history, status, and future of regional science. The Review of Regional Studies 23: 1-50

Jin C, Grissom TV (2008) Forecasting Dynamic Investment Timing under the Cyclic Behavior in Real Estate. International Real Estate Review 11: 105-125

Jones C (1995) An economic basis for the analysis and prediction of local office property markets. Journal of Property Valuation and Investment 13: 16-30

Kapetanios G, Labhard V, Price S (2008) Forecast combination and the Bank of England's suite of statistical forecasting models. Economic Modelling 25: 772-792

Karakozova O (2004) Modelling and forecasting office returns in the Helsinki area. Journal of Property Research 21: 51-73

Kohlert D (2010) The determinants of regional real estate returns in the United Kingdom: A vector error correction approach. Journal of Property Research 27: 87-117

Koschinsky J, Koster S, Patuelli R, Royuela V, Tselios V (2014) Editorial: REGION the online open-access journal of ERSA. REGION 1: 1-3

Lee S (1998a) The relative importance of sectors v's regions in determining property returns. Paper presented at the Pacific Rim Real Estate Society (PRRES) Conference, Perth, Western Australia

Lee S (1998b) Sector and regional factors in real estate returns. Paper presented at the American Real Estate Society (ARES) Meeting, Monterey, CA

Lee S, Stevenson S (2005) Testing the statistical significance of sector and regional diversification. Journal of Property Investment \& Finance 23: 394-411

Mahmoud E (1984) Accuracy in Forecasting: A survey. Journal of Forecasting 3: 139-159

Makridakis S (1981) Forecasting accuracy and the assumption of constancy. Omega 9: $307-311$

Makridakis S (1989) Why combining works? International Journal of Forecasting 5: 601-603

Makridakis S, Wheelwright S, Hyndman R (1998) Forecasting: Methods and Applications (3rd ed.). John Wiley \& Sons, Inc., New York

Malizia E, Simons R (1991) Comparing regional classifications for real estate portfolio diversification. Journal of Real Estate Research 6: 53-78

McAllister P, Kennedy P (2007) Data uncertainty in real estate forecasting. Working Papers in Real Estate \& Planning rep-wp2007-06, University of Reading

McAllister P, Newell G, Matysiak G (2005) An evaluation of the performance of UK real estate forecasters. Working Papers in Real Estate \& Planning rep-wp2005-23, University of Reading

Newell G, Acheampong P, Karantonis A (2002) The accuracy of property forecasting. Paper presented at the Pacific Rim Real Estate Society (PRRES) Conference, Christchurch, New Zealand

Newell G, MacFarlane J (2006) The accuracy of commercial property forecasting in Australia. Pacific Rim Property Research Journal 12: 311-325 
Orrell D, McSharry P (2009) System economics - overcoming the pitfalls of forecasting models via a multidisciplinary approach. International Journal of Forecasting 25: 734743

Pagourtzi E, Assimakopoulos V, Litsa A (2005) Theta model forecasts of quarterly and monthly dwelling prices in the UK. Briefings in Real Estate Finance 5: 75-105

Pesaran M, Pick A (2011) Forecast combination across estimation windows. Journal of Business and Economic Statistics 29: 307-318

Rapach D, Strauss J (2007) Forecasting real housing price growth in the Eighth District States. Regional Economic Development 3: 33-42

Rosen K (1984) Toward a model of the office building sector. Real Estate Economics 12: 261-269

Smith K, Shulman D (1976) The performance of equity real estate investment trusts. Financial Analysts Journal 32: 61-66

Stevenson S, McGarth O (2003) A comparison of alternative rental forecasting models: Empirical tests on the London office market. Journal of Property Research 20: 235-260

Stock J, Watson M (2004) Combination forecasts of output growth in a seven-country data set. Journal of Forecasting 23: 405-430

Tsolacos S (1995) An econometric model of retail rents in the United Kingdom. The Journal of Real Estate Research 10: 519-529

Wallis K (2011) Combining forecasts - forty years later. Applied Financial Economics 21: $33-41$

Wheaton W (1987) The cyclical behaviour of the national office market. Journal of American Real Estate and Urban Economics Association 15: 281-299

Wilson P, Okunev J, Ellis C, Higgins D (2000) Comparing univariate forecasting techniques in property markets. Journal of Real Estate Portfolio Management 6: 283-306

Wood S (1976) Combining forecasts to predict property values for single-family residences. Land Economics 52: 221-229 